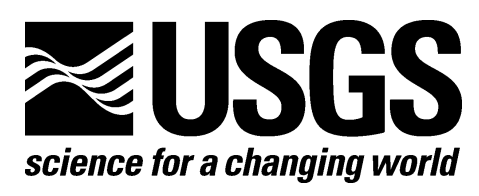

\title{
Elevation Derivatives for Mojave Desert Tortoise Habitat Models
}

\section{Manuscript}

By Cynthia S.A. Wallace and Leila Gass

Open-File Report 2008-1283

U.S. Department of the Interior U.S. Geological Survey 


\title{
U.S. Department of the Interior DIRK KEMPTHORNE, Secretary
}

\author{
U.S. Geological Survey \\ Mark D. Myers, Director
}

U.S. Geological Survey, Reston, Virginia 2008

For product and ordering information:

World Wide Web: http://www.usgs.gov/pubprod

Telephone: 1-888-ASK-USGS

For more information on the USGS - the Federal source for science about the Earth, its natural and living resources, natural hazards, and the environment:

World Wide Web: http://www.usgs.gov

Telephone: 1-888-ASK-USGS

Any use of trade, product, or firm names is for descriptive purposes only and does not imply endorsement by the U.S. Government.

Although this report is in the public domain, permission must be secured from the individual copyright owners to reproduce any copyrighted material contained within this report. 


\section{Contents}

Abstract

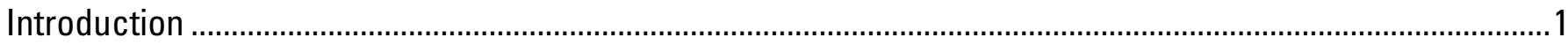

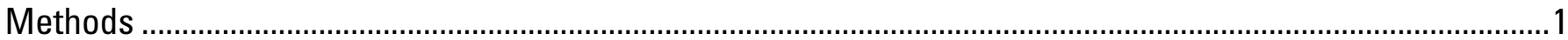

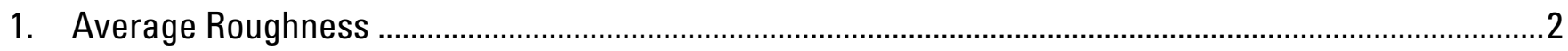

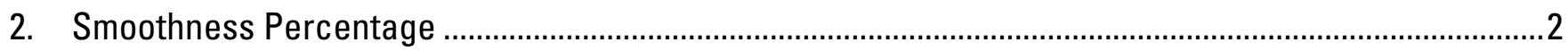

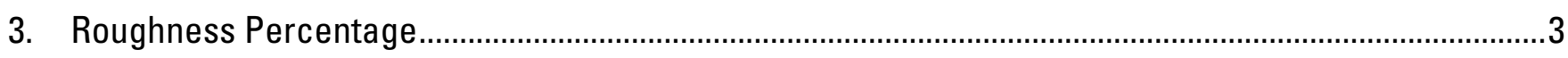

4. Aspect Standard Deviation .................................................................................................................

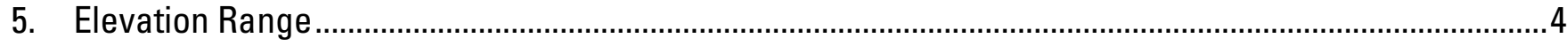

6. Elevation Standard Deviation................................................................................................................

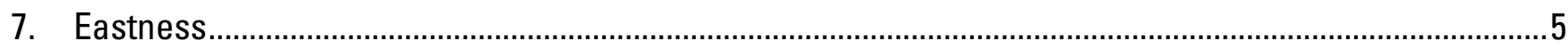

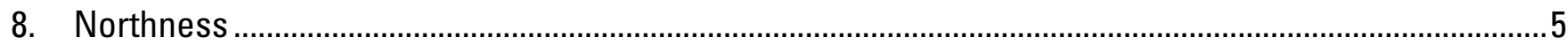

9. Slope

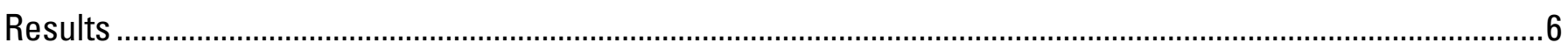

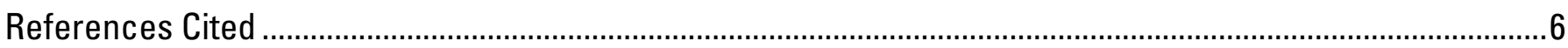




\title{
Elevation Derivatives for Mojave Desert Tortoise Habitat Models
}

By Cynthia S.A. Wallace and Leila Gass

\begin{abstract}
This report describes the methods used to derive various elevation-derivative grids that were inputted to the Mojave Desert Tortoise Habitat model (L. Gass and others, unpub. data). These grids, which capture information on surface roughness and topographic characteristics, are a subset of the environmental datasets evaluated for the tortoise habitat model. This habitat model is of major importance to the U.S. Fish and Wildlife Service, which is charged with management of this threatened population, including relocating displaced tortoises to areas identified as suitable habitat.
\end{abstract}

\section{Introduction}

Field observations suggest that topographic characteristics are important in defining desert tortoise habitat. Tortoises avoid steep areas and high-elevation terrains but do use slopes and rocky terrain (U.S. Fish and Wildlife Service, 1994). To incorporate these environmental traits into habitat modeling, we created several elevation derivatives to capture different landscape roughnesses and topographic characteristics.

\section{Methods}

All elevation-derivative maps were derived from standard U.S. Geological Survey (USGS) 30-m National Elevation Database (NED) digital-elevation-model (DEM) data (URL http://ned.usgs.gov/). A 
total of nine measures were calculated at 30-m resolution and then summarized over both 250-m and 1-km cell resolution for use in modeling tortoise habitat. These measures and their derivations are summarized below.

\section{Average Roughness}

The Average Roughness grid captures the simple average of a group of cells. Note that as the cell size of the derived grid increases (i.e., the resolution decreases), the derived grid becomes smoother.

A Surface Ratio grid was calculated by using the ArcView extension surfgrids.avx (Jenness 2002), which uses an existing elevation grid and calculates "Surface Area" and "Surface Ratio" for the land area contained within that cell's boundaries. The Surface Area is a function of the slope, aspect, and planimetric area of the cell (Jenness, 2002), where Surface Ratio $=($ Surface Area) $/$ (planimetric

area). These measures provide useful indices of topographic roughness. The Average Roughness is the average Surface Ratio of the 30-m cells within each 250-m or 1-km model cell.

\section{Smoothness Percentage}

The Smoothness Percentage grid preserves details of the "smooth" end of the spectrum of roughness information present in the original 30-m grid. This preservation was accomplished by first classifying the 30-m cells as either "smooth" or "not smooth" on the basis of a user-defined threshold, and then calculating the percentage of "smooth" cells within the derived grid cell. In contrast to calculating a simple average, increasing the cell size of the derived grid does not systematically affect the derived values.

A binary grid was created from the 30-m Surface Ratio grid (see sec. 1) to identify the "smoothest" approximately 25 percent of the image. The threshold selected based on image statistics is a roughness of 1.01 (the first quartile). Thus, in the binary grid, all cells coded with roughness less than 1.01 were recoded as 1 and those with roughness greater than or equal to 1.01 were recoded as 0 . The 
percentage of the smooth terrain (percentage of cells with binary values of 1) within each 250-m or 1-km model cell was then calculated to produce the Smoothness Percentage grid.

\section{Roughness Percentage}

The Roughness Percentage grid preserves details of the "rough" end of the spectrum of roughness information present in the original 30-m grid. This preservation was accomplished by first classifying the 30-m cells as either "rough" or "not rough" on the basis of a user-defined threshold, and then calculating the percentage of "rough" cells within the derived grid cell. In contrast to calculating a simple average, increasing the cell size of the derived grid does not systematically affect the derived values.

A binary grid was created from the 30-m Surface Ratio grid (see sec. 1) to identify the "roughest" approximately 25 percent of the image. The threshold selected based on image statistics is a roughness of 1.11 (the third quartile). Thus, in the binary grid, all cells coded with roughness greater than or equal to 1.11 were recoded as 1 , and those with roughness less than 1.11 were recoded as 0 . The percentage of the smooth terrain (percentage of cells with binary values of 1) within each 250-m or 1-km model cell was then calculated to produce the final Roughness Percentage grid.

\section{Aspect Standard Deviation}

The Aspect Standard Deviation grid captures another measure of landscape roughness. A rough landscape will be composed of surfaces that are oriented along various aspects. Such a landscape will display a large Aspect Standard Deviation, whereas a uniformly sloping surface will display a small Aspect Standard Deviation, if not a single aspect. Increasing the cell size of the derived grid will likely increase the Aspect Standard Deviation, owing to the larger number of 30-m cells included in the calculation. 
To derive this measure, two aspect grids were generated in ArcInfo, using the 30-m NED DEM as input. In the first grid, called aspect0n, we defined $\mathrm{N}$ as aspect $=0^{\circ}$ and $\mathrm{S}$ as aspect $=180^{\circ}$. A second aspect grid, called aspect0s, was oriented in the opposite direction, with $\mathrm{S}$ as aspect $=0^{\circ}$ and $\mathrm{N}$ as aspect $=180^{\circ}$. In addition, a binary grid was created to identify flat areas with slope $<1^{\circ}$, coded as minus 1 . Within each model cell, we calculated the standard deviation of aspect0n (ignoring flat terrain), the standard deviation of aspect0s (ignoring flat terrain), and the percentage of flat terrain. The final grid value is the minimum of the two standard deviations (to eliminate high standard deviations due to slopes that straddle the circular scale at $0^{\circ}$ and $360^{\circ}$ ), with a value of minus 1 assigned to all cells with more than 50 percent flat terrain.

\section{Elevation Range}

The Elevation Range grid is simply the maximum minus the minimum elevation of the $30-\mathrm{m}$ DEM cells within each 250-m or 1-km model cell. A rough surface or a smooth sloping surface will display a larger Elevation Range than a smooth horizontal surface. Note that increasing the cell size of the derived grid will likely increase the Elevation Range, owing to the larger number of 30-m cells included in the calculation.

\section{Elevation Standard Deviation}

The Elevation Standard Deviation grid is simply the standard deviation of the 30-m DEM cells within each $250 \mathrm{~m}$ or $1-\mathrm{km}$ model cell. A rough surface or a smooth sloping surface will display a larger Elevation Standard Deviation than a smooth horizontal surface or a horizontal surface with an isolated high peak. Note that increasing the cell size of the derived grid will likely increase the Elevation Standard Deviation, owing to the larger number of 30-m cells included in the calculation. 


\section{Eastness}

The easterly aspect of each cell was calculated by using the "eastness" metric of Zar (1999), as follows:

$$
\text { Eastness }=\sin \left(\frac{\text { aspect } \times \pi}{180}\right)
$$

This formula converts the aspects of $0^{\circ}-360^{\circ}$, where $0^{\circ}$ and $360^{\circ}=$ north and $180^{\circ}=$ south, into values between minus 1 and 1 , where minus $1=$ west and $1=$ east. In this grid, high values are oriented more easterly than low values. Eastness was calculated on the 30-m DEM grid and then resampled to 250-m and 1-km grids by using bilinear interpolation.

\section{Northness}

The northerly aspect of each cell was calculated by using the "northness" metric of Zar (1999), as follows:

$$
\text { Northness }=\cos \left(\frac{\text { aspect } \times \pi}{180}\right)
$$

This formula converts the aspects of $0^{\circ}-360^{\circ}$, where $0^{\circ}$ and $360^{\circ}=$ north and $180^{\circ}=$ south, into values between minus 1 and 1 , where minus $1=$ south and $1=$ north. In this grid, high values are oriented more northerly than low values. Northness was calculated on the 30-m DEM grid and then resampled to 250-m and 1-km grids by using bilinear interpolation.

\section{Slope}

The Slope was calculated as the maximum rate of change in $z$-value (elevation) between each cell of the DEM and its eight neighbors. The $30-\mathrm{m}$ DEM was first resampled to $250-\mathrm{m}$ and 1-km grids by using bilinear interpolation, and then slope was calculated from each of the resampled DEM grids. 


\section{Results}

The nine derived roughness measures summarized over 250-m- and 1-km-grid cell sizes were delivered to the desert tortoise habitat modeling team as ArcInfo grids. On the basis of recommendations from USGS tortoise biologists, six of the datasets described here were used in modeling tortoise habitat: Average Roughness, Smoothness Percentage, Roughness Percentage, Eastness, Northness, and Slope.

To determine which datasets were the best predictors of tortoise presence, a decision-tree analysis was applied to all environmental variables used in the habitat models. Decision trees (Breiman et al., 1984), also known as classification and/or regression trees, provide a nonparametric quantitative approach to examining the relations between input and response variables. The decision tree was applied iteratively, with the environmental variable contributing least to predicting the response variable (tortoise presence) removed for each subsequent run. Using this analysis, the project team identified six environmental variables that contributed the most toward predicting tortoise presence. Of the six elevation-derivative grids, Average Roughness was retained by the decision tree and therefore was most predictive of suitable tortoise habitat.

\section{References Cited}

Breiman, L., Friedman, J.H., Ohshen, R.A. and Stone, C.J., 1984, Classification and Regression Trees: Belmont, Calif., Wadsworth International Group, 368 p.

Jenness, J., 2002, Surface Areas and Ratios from Elevation Grid (surfgrids.avx) Extension for ArcView 3.x, v. 1.2: [http://www.jennessent.com/arcview/surface_areas.htm, accessed July 16, 2008]. 
U.S. Fish and Wildlife Service, 1994, Desert Tortoise (Mojave Population) Recovery Plan: Portland, Oreg., 73 p.

Zar, J.H., 1999, Biostatistical Analysis (4th ed): Prentice Hall, Upper Saddle River, N.J., 931 p. 